\title{
PRESIDENTIAL RECORDS
}

Adapted from the remarks of Dr. John Brademas, President Emeritus, New York University, and former Member of Congress (1959-1981) at a symposium, "Presidential Records," cosponsored by the Archivists Round Table of Metropolitan New York, New York University Program in Archival Management and Historical Editing, and the New York University Archives. Held at Jurow Lecture Hall, New York University, 100 Washington Square East, 6:15 p.m., Tuesday, February 26, 2002.

AlLOW ME TO OBSERVE that the Executive Order of President Bush of November 1, 2001, blocking access to the records of Presidents Reagan and the first President Bush, in circumvention of the requirements of the Presidential Records Act of 1978; the dispute concerning the papers of Mayor Giuliani of New York; the suit by the General Accounting Office against Vice President Cheney because of his refusal to provide names of the persons who took part in his secret Energy Task Force meetings; and the controversy over the decision by Governor Bush of Texas to send his records as governor not to the Texas State Library and Archives but, instead, to his father's presidential library-these are all recent developments that help shape the environment for this commentary.

The subject is one with which I myself first became involved nearly 28 years ago as a Member of the Congress of the United States.

My attention to the question of the handling and disposition of the records of American presidents was renewed last fall when I took part in a conference titled "The Future of Presidential Libraries" in Austin, 
Texas, during ceremonies marking the thirtieth anniversary of the dedication of the Lyndon B. Johnson Library at the University of Texas, an event I attended.

So let me explain my relationship to this issue.

I served in Congress, from Indiana, from 1959 to 1981, 22 years, the last four as Majority Whip of the House of Representatives.

My principal committee assignment was Education and Labor, where I took part in writing all the legislation enacted during those years to assist schools, colleges, and universities; the arts and the humanities; libraries and museums; and services for children, the elderly, and the disabled.

I also served on the Committee on House Administration, responsible for, among other matters, campaign finance legislation, and on the Joint (House-Senate) Committee on the Library of Congress.

With that background, let me tell of my involvement in the issue of presidential records.

After President Gerald Ford, newly installed in office, announced on September 8, 1974, that he had granted an unconditional pardon to Richard Nixon for any crimes he may have committed, the Ford White House also released the letter of September 6 from Mr. Nixon to Arthur F. Sampson, then administrator of the General Services Administration, concerning the papers and tape recordings of the Nixon presidency.

This letter stipulated that Mr. Nixon would retain control over his papers and the recordings under conditions that required destruction of the tapes at the time of Nixon's death or on September 1, 1984-that is to say, 10 years later-whichever event first occurred.

Moreover, the letter, to which Sampson agreed, provided that after five years, Nixon would be free to order the destruction of any of the tapes. 
On learning of this agreement, I was outraged. Why?

First, I was at the time a member (from 1971 through 1976), by appointment of House Speaker Carl Albert, of the National Historical Publications and Records Commission, serving with Senator Claiborne Pell of Rhode Island, Supreme Court Justice William Brennan, and some eminent American historians. Chairing the Commission was James B. "Bert" Rhodes, Archivist of the United States. The Commission met quarterly in the National Archives Building to decide on grants to scholars for publishing materials on American history.

Second, I had written a little history myself, in the form of a Ph.D. dissertation at Oxford, later published in Barcelona, on the anarchosyndicalist movement in Spain from the mid-1920s through the first year of the Spanish Civil War.

Third, I had no particular respect for Richard Nixon. I was well aware of the nature of his congressional campaigns in California, and I had served on the staff of Adlai Stevenson during his 1955-1956 presidential campaign.

Moreover, I had been named, to the envy of my Democratic colleagues in the House of Representatives, to Nixon's "White House Enemies List."

There was a final reason for my response to the deal between Nixon and GSA. I thought, "Nazis burn books; Americans don't burn books!"

So I approached the then chairman of the House Government Operations Committee, which had jurisdiction over GSA, Jack Brooks of Texas, and said, "Jack, what're you going to do about this?" Jack replied, "John, this is September of an election year. I don't have time to do anything." 
I responded, "Jack, I'm chairman of the most inconsequential subcommittee in the U.S. House of Representatives, the Subcommittee on Printing of House Administration." Our subcommittee told members how many Capitol Hill calendars they could send to their constituents. But the subcommittee gave me a color of jurisdiction, and Jack said, "You've got it!"

My subcommittee colleagues and I quickly coordinated our efforts with Senator Gaylord Nelson of Wisconsin, who was taking the lead in the Senate on legislation to abrogate the Nixon-Sampson agreement. Because of House rules on committee jurisdiction, however, our initial proposal in my subcommittee could not include such language.

On September 30 and October 4, 1974, I conducted hearings in the Subcommittee on Printing on a bill I had introduced jointly with the ranking Republican on the subcommittee, Orval Hansen of Idaho, to establish a national commission to study issues dealing with the disposition and preservation of records and documents of Federal officials.

The subcommittee also heard testimony on related bills, introduced by Representatives Jonathan Bingham of New York and Thomas A. Luken of Ohio, directing that the "public documents" of all elected Federal officials be turned over to the Federal Government while Representative John F. Sieberling of Ohio had introduced a bill to include the records only of the president and vice president.

Testifying in support, in whole or in part, of these proposals, were archivists, historians, legal scholars, and John S.D. Eisenhower, son of President Eisenhower.

Meanwhile, in the Senate, the redoubtable Sam Ervin of North Carolina was also moving, and on September 26, 1974, the Committee on Government Operations, which Senator Ervin chaired, unanimously, 
Democrats and Republicans joining, and without having conducted any hearings, reported a bill, S.4016, specifically directed to killing the Nixon-Sampson deal and mandating ownership of the Nixon materials by the Federal government.

The Senate passed the Ervin Bill on October 4; it was referred, on October 7, 1974, to the House Administration Committee and to the subcommittee I chaired, another of whose members, by the way, was a Representative from New York, Edward I. Koch.

Because of business in the House arising from presidential vetoes, the Senate-passed bill could not be considered by the House before the election recess on October 17. In a statement on October 16, I assured the House of my "intention to bring this bill to the attention of the subcommittee the first week the House reconvenes in November."

In the meantime, I was engaged in correspondence (October 9, 1974) with Philip W. Buchen, Counsel to President Ford, seeking "assurances that the tapes and related materials would not be destroyed, damaged, or removed from Washington during that time."

Receiving as of October 16 no reply from Mr. Buchen and, more to the point, responding to a Nixon legal brief asserting that a president's papers are his private property, I joined Senators Ervin, Gaylord Nelson, and Jacob Javits and House Administration Committee Chairman Wayne Hays in filing, on November 11, an amici curiae memorandum in the U.S. District Court for the District of Columbia. My colleagues and I urged the court, by maintaining an existing stay, to assure protection of the materials until Congress had completed action on the relevant pending legislation.

On November 20, joined by both Democratic and Republican members of the printing subcommittee, I introduced H.R.17484, which included the language both of the Senate-passed bill nullifying the Nixon- 
Sampson agreement and of my subcommittee bill to establish a national commission to study issues involving the disposition of records of federal officials.

On November 26, the printing subcommittee marked up the Senatepassed bill and added a title authorizing the public documents commission. By a vote of 20 to 0 , the full Committee on House Administration then favorably reported the measure.

On December 3, 1974, the House of Representatives, acting under Suspension of the Rules, approved the bill; on December 9, the Senate agreed, with some technical amendments, to the House amendments; the House immediately accepted the Senate bill and technical amendments; and the bill went to the White House.

On December 19, 1974, President Ford signed into law the Presidential Recordings and Materials Preservation Act, which, as I have said, nullified the Nixon-Sampson agreement and declared that all the Nixon papers and tape recordings belonged to the people of the United States. This is, of course, the statute that makes possible the occasional publication of transcripts of the Nixon tapes.

I cannot here resist recalling the title of a George Will column in the Washington Post in 1977: "The Nixon Tapes Must Be Destroyed."

The 17 National Study Commission on Records and Documents of Federal Officials, created by the bill, was chaired by former Attorney General Herbert Brownell and produced its final report on March 31, 1977.

The most important result of the Commission's report was the Presidential Records Act of 1978, which, as you know, now governs the papers of presidents. They can no longer claim title to their papers. President Reagan is the first president to be affected by the 1978 statute. I was one of the cosponsors of the measure. 
Although the 1978 act calls for public release of records of presidents 12 years after they have left office, as everybody here knows, in an Executive Order issued on November 1 of last year, President Bush seeks, in the minds not only of several historians and archivists, but of some Republican Members of Congress as well, to unravel the 1978 law by refusing to release the records of President Reagan and George Bush the First.

Republican Congressman Stephen Horn of California, who chairs a subcommittee on government reform, at a hearing on November 6, urged the president to rescind the Executive Order while another California Republican, Doug Ose, warned, "This new order undercuts the public's right to be fully informed about how its government operated."

Richard Reeves, author of the recent book, President Nixon: Alone in the White House, in a New York Times op-ed essay (November 16, 2001) was harsher still: "With a stroke of the pen on Nov. 1, President Bush stabbed history in the back and blocked Americans' right to know how presidents (and vice presidents) have made decisions. Executive Order 13223 ended more than 30 years of increasing openness in government."

The reason for the order, Reeves suggests: "There may be Reagan-era records that could be embarrassing to some men and women now back in power with a second Bush administration.

"Perhaps even more pertinent," Reeves adds, "they may not want to spend their retirements 12 years after George W. Bush leaves office, defending the wartime decisions they are making now."

I shall not here recite the attacks levied on the Bush order by the Washington Post, Los Angeles Times, San Francisco Chronicle, Christian 
Science Monitor, and the New York Times, but these major American dailies have been unsparing in their criticism.

As chief House author of the 1974 act and cosponsor of the 1978 statute, I trust my views on President Bush's Executive Order are clear.

Allow me, however, a brief comment about a subject that, if not central to this discussion, is, I think, directly related. I speak of the papers of former members of the United States Senate and House of Representatives.

Some personal words. My own papers cover 22 years as a member of the House of Representatives. I served with six presidents-three Republicans: Eisenhower, Nixon, and Ford; and three Democrats: Kennedy, Johnson, and Carter. During my last four years, I was, by appointment of Speaker Thomas P. “Tip” O’Neill, House Majority Whip.

During my service as Whip, I joined Speaker O'Neill, Senate Majority Leader Robert C. Byrd, House Majority Leader Jim Wright, Senator Hubert H. Humphrey (while he lived), and the other Democratic leaders of Congress for breakfast nearly every other Tuesday at the White House with President Carter and Vice President Mondale.

I hope to make use of my notes, over two decades later, for a study of how a president deals with the leaders of his own party in Congress.

A few weeks ago, thanks to the work of Nancy Cricco, Archivist of New York University, my papers were brought from a Library of Congress warehouse to New York University where, I understand, Peter Wosh, professor at NYU, will be using them as materials for a class he teaches on the management of historical archives.

Let me make just one other observation. On the admonition of my Oxford classmate and longtime friend, the eminent historian of Russian culture and distinguished Librarian of Congress, James $\mathrm{H}$. 
Billington, I hope to use my papers as the seed for creating, at New York University, a Center for the Study of Congress.

My motive for wanting to establish a center for serious academic attention to the Congress of the United States is straightforward. In a separation-of-powers constitutional system like ours with, compared to European parliamentary arrangements, relatively undisciplined political parties, when it comes to the making of national policy, Congress counts! This is a lesson that President George W. Bush is learning daily.

So I want to establish a center in New York City that will have two principal dimensions: first, it will be a place where scholars can engage in research on and study of Congress as a policy-making institution; and second, it will be a place to bring practitioners-senators and congressmen, current and former; congressional staffers; persons from the executive branch; scholars; journalists; and parliamentarians from other countries - to interact with academics at New York University. Such a center would, of course, be wholly bipartisan.

Beyond voicing my particular aspiration, I want now to say that I believe the time has come for the Federal Government to fashion a more rational, orderly public policy for dealing with the papers of senators and congressmen. Accordingly, in preparing for my visit to Austin last fall, I was pleased to learn of the existence of the Congressional Papers Forum of the Society of American Archivists, a group that has been meeting for nearly 15 years to discuss how to handle the records of former members of the United States Senate and House of Representatives.

I shall here recall the words of David McCullough at a joint session of Congress in 1989: "Two hundred years after the creation of Congress we have only begun to tell the story of Congress-which, of course, means the opportunity for those who write and who teach could not be greater." 